\title{
Typhoid Fever in Nineteenth-Century Colombia: Between Medical Geography and Bacteriology
}

\author{
MÓNICA GARCÍA* \\ Universidad del Rosario, Escuela de Ciencias Humanas, Calle 6A No. 14-13, \\ Of. 504, Bogotá, Colombia
}

\begin{abstract}
This paper analyses how the Colombian medical elites made sense of typhoid fever before and during the inception of bacteriological ideas and practices in the second half of the nineteenth century. Assuming that the identity of typhoid fever has to be understood within the broader concerns of the medical community in question, I show how doctors first identified Bogotá's epidemics as typhoid fever during the 1850s, and how they also attached specificity to the fever amongst other continuous fevers, such as its European and North American counterparts. I also found that, in contrast with the discussions amongst their colleagues from other countries, debates about typhoid fever in 1860-70 among doctors in Colombia were framed within the medico-geographical scheme and strongly shaped by the fear of typhoid fever appearing alongside 'paludic' fevers in the highlands. By arguing in medico-geographical and clinical terms that typhoid fever had specificity in Colombia, and by denying the medico-geographical law of antagonism between typhoid and paludic fevers proposed by the Frenchman Charles Boudin, Colombian doctors managed to question European knowledge and claimed that typhoid fever had distinct features in Colombia. The focus on paludic and typhoid fevers in the highlands might explain why the bacteriological aetiology of typhoid fever was ignored and even contested during the 1880s. Anti-Pasteurian arguments were raised against its germ identity and some physicians even supported the idea of spontaneous origin of the disease. By the 1890s, Pasteurian knowledge had come to shape clinical and hygienic practices.
\end{abstract}

Keywords: Typhoid Fever, Medical Geography, Bacteriology, Colombia, History of Medicine, Fevers

\footnotetext{
*Email addresses for correspondence: claudia.garcia@urosario.edu.co, cmonicagarcia@gmail.com This work has been supported by the European Union Programme of High Level Scholarships for Latin America (grant number E05D056876CO). I am grateful to the editors and the anonymous referees of the article for suggestions and revisions.
} 


\section{Introduction}

In 1882 Colombian doctor Alberto Roca affirmed that fevers appearing in the capital city, Bogotá, were of a typhoid remittent bilious nature and that they could be associated with a malarial or 'paludic' element. ${ }^{1}$ The country's most important medical association, the Sociedad de Medicina y Ciencias Naturales of Bogotá (SMCN, Society of Medicine and Natural Sciences), decided to evaluate this unsettling diagnosis. Its members were arguably concerned since Bogotá is located in the highlands, in the eastern branch of the Andes Mountains, far away from Colombia's coastlines and river valleys where malarialike fevers were expected to occur. The society appointed Gabriel J. Castañeda to study Roca's report. With both enthusiasm and naiveté, Castañeda defended the idea that the fevers were of a typhoid nature and that they were caused by the novel object of the time, germs. ${ }^{2}$ Interestingly, one of the spokesmen of the society, Nicolás Osorio, criticised Castañeda's opinions, claiming that he had failed to address the most pressing questions: 'Did paludic fevers exist in Bogotá? Could typhoid fever take the form of an intermittent fever?' ${ }^{3}$ Osorio's anxiety reflects a decade of debates in which Colombians mobilised medico-geographical arguments in order to make sense of the possibility of typhoid and paludic fevers happening alongside each other in the highlands. His indifference to the new Pasteurian germ hypothesis, by contrast, announced a decade of anti-Pasteurian arguments that would henceforward characterise Colombian debates on typhoid fever. In these debates, Colombian scientists shaped a specific frame of typhoid fever that contrasts sharply with dominant European theories.

Indeed, historians who have investigated the history of typhoid fever in the nineteenth century have explored how the typhoid fever variety first acquired a specific identity in the 1830 s on the basis of clinical and anatomopathological criteria, that is, through the detection of rose-coloured lenticular spots and diarrhoea, and in death caused by pathological changes in Peyer's patches of the small intestine as described by the French Pierre A. Louis. ${ }^{4}$ Historians have also detailed how North American, British and French physicians using the same criteria came to establish by 1860 that typhoid and typhus fevers were two different kinds of continuous fevers. Thus, while scholars have focused on how typhoid fever gained its anatomopathological identity, few have situated the ideas about it in the broader context of the climatic and medico-geographical concerns regarding fevers at that time. As this paper will show, in contrast to what historians have shown for Europe and the United States, debates about the nature of typhoid fever in Colombia provoked concern regarding the geographical determination of diseases.

\footnotetext{
${ }^{1}$ Alberto de J. Roca, 'Fiebre tifoidea remitente biliosa: Estudio clínico’, Revista Médica, 76 (1882), 146-7.

${ }^{2}$ Gabriel J. Castañeda, 'Informe sobre el trabajo de E. de J. Roca titulado "fiebre tifoidea remitente biliosa", Revista Médica, 87 (1883), 83-4.

${ }^{3}$ Ibid., 93.

4 To mention a few: Vincent J. Cirillo, 'Fever and Reform: The Typhoid Epidemic in the Spanish-American War', Journal of the History of Medicine and Allied Sciences, 55 (2000), 363-97; Michael P. McCarthy, Typhoid and the Politics of Public Health in Nineteenth-Century Philadelphia (Philadelphia, PA: American Philosophical Society, 1987); K. David Patterson, 'Typhus and its Control in Russia, 1870-1940', Medical History, 37 (1993), 363-81; Dale C. Smith, 'Gerhard's Distinction Between Typhoid and Typhus and its Reception in America, 1833-1860', Bulletin of the History of Medicine, 54, 3 (1980), 368-85, and 'The Rise and Fall of Typhomalarial Fever', Journal of the History of Medicine and Allied Sciences, 37 (1982), 182-220, 287-321; Lloyd G. Stevenson, 'A Pox of the Ileum: Typhoid Fever among the Exanthemata', Bulletin of the History of Medicine, 51 (1977), 496-505; and Leonard G. Wilson, 'Fevers and Science in Early Nineteenth Century Medicine', Journal of the History of Medicine and Allied Sciences, 33 (1978), 386-407.
} 
Few historians have claimed that controversies about the nature of typhoid fever had finished by the time of the discovery of the typhoid germ in $1880 .{ }^{5}$ However, little attention has been given to the impact of bacteriology in identifying this fever whether in Europe, the US or in Latin American contexts. ${ }^{6}$ Colombian doctors showed little interest in the new theory of the germ identity of typhoid during the 1880 s.

Scholars who have explored the history of bacteriology over the last two decades have described it as having 'many different meanings assigned to it in debates over specific diseases, at different points in time, across national boundaries, and among different classes and ethnic groups'. ${ }^{7}$ This approach coincides with the standpoint of Latin American scholars regarding the history of bacteriology in the region. ${ }^{8}$ Instead of treating bacteriology as a science produced in some 'centres' that spread to the 'peripheries', they have tried to understand the local meanings and practices on their own terms. Thus, following the idea that bacteriology had not one but diverse meanings, and drifting away from the 'centre-periphery' approach, I assume here that bacteriology first made sense to Colombian physicians within their own theoretical and practical traditions. These traditions combined nosology, anatomopathology and medical geography. I show that typhoid fever had become relevant to the medical elite by 1870 in the debates surrounding periodic fevers and their medico-geographical determination. Colombian meanings of and practices relating to typhoid fever were deeply entrenched in those traditions when Pasteurian bacteriology was introduced in the 1880s. The discussions regarding the germ identity of the fever illustrates the challenges that the new theory posed for clinicians in general.

In the first section I show how doctors had integrated nosology, anatomopathology and the climatological determinism of fevers into the understanding of typhoid fever by 1850 , and how typhoid fever gained specificity amongst continuous fevers during that decade. In the following four sections I analyse the debates about typhoid fever held by the medical elite from the 1850 s to the early 1880 s. In particular, I explore how these debates were shaped by the medico-geographical approach to diseases, by the fear of periodic fevers and by the new clinical thermometry as well. In the last three sections I show the way in which bacteriology was introduced in considerations and management of typhoid fever during the 1880s. Here I detail the arguments against the new identity and how doctors came to terms with it at the end of the century.

\footnotetext{
${ }^{5}$ Jacob Steere-Williams, 'The Perfect Food and the Filth Disease: Milk-borne Typhoid and Epidemiological Practice in Late Victorian Britain', Journal of the History of Medicine and Allied Sciences, 65, 4, 515.

${ }^{6}$ One exception would be Luis Antonio Teixeira, 'As fiebres paulistas na Sociedade de Medicina e Cirurgia de Sao Paulo: Uma controvérsia entre porta-vozes de diferentes saberes', História, Ciências, Saúde-Manguinhos, Rio de Janeiro, 11 (suplemento 1, 2004): 41-66.

${ }^{7}$ Nancy Tomes and John Harley Warner, 'Introduction to Special Issue on Rethinking the Reception of the Germ Theory of Disease: Comparative Perspectives', Journal of the History of Medicine, 52, January (1997), 12; See also Michael Worboys, Spreading Germs: Disease Theories and Medical Practice in Britain, 1865-1900 (Cambridge: Cambridge University Press, 2000).

${ }^{8}$ Diana Obregón, 'Sobre epidemias, endemias y epizootias: Algunos aspectos del desarrollo de la bacteriología en Colombia', Biomédica, 18, 2 (1998), 110-21; and 'The Social Construction of Leprosy in Colombia, 1884-1939’, Science, Technology and Society, 1, 1 (1996), 1-23; Jaime Larry Benchimol, Dos micróbios aos mosquitos: Febre amarela e a revolução pasteuriana no Brasil (Rio de Janeiro: Editora Fiocruz, 1999); and Marcos Cueto, 'Nationalism, Carrión's Disease and Medical Geography in the Peruvian Andes', History and Philosophy of the Life Sciences, 25 (2003), 319-35.
} 


\section{Continuous Fevers and Typhoid Fevers by 1860}

One of the earliest accounts of a fever reputed to be a typhoid-like fever in Colombia was given by Antonio Vargas. ${ }^{9}$ Vargas had trained as a doctor in Bogotá during the $1830 \mathrm{~s}$ and then attended the very prestigious Medical School of Paris between 1845 and 1847. Upon his return to Colombia, Vargas led the process of consolidating the country's rather fragmented medical profession. Indeed, traditional practitioners had been responsible for medical care ever since colonial times and the liberal reforms of the mid-nineteenth century had eliminated the requirement of a university qualification for medical practice. Vargas, along with locally trained physicians and a handful of other doctors returning from the Paris Medical School, founded Colombia's first medical journals (1852 and 1864). They also established the basis of the medical training at the Universidad Nacional de Colombia in 1868 and created the country's first medical association, the Sociedad de Medicina y Ciencias Naturales de Bogotá (SMCN), in 1873. Around half of the eighteen doctors that formed this new society had either earned their medical degrees at the Medical School of Paris or taken courses in France in fields such as surgery and obstetrics. ${ }^{10}$ The SMCN became the official advisor on hygiene until the creation of a central hygiene board, the Junta Central de Higiene (JCH), in 1886. It also edited the Revista Médica; this publication and the JCH Revista de la Junta Central de Higiene became the two most important Colombian medical journals of the century.

Vargas and the pioneers of this consolidation of the Colombian medical corps argued that they were creating a national tradition of medicine. This involved establishing the institutional basis for the medical profession and drawing boundaries between doctors and other practitioners, but most importantly, it implied developing a corpus of doctrine derived from the investigation of local pathologies, ailments produced by specific climatic conditions. ${ }^{11}$ That was the case with some essential fevers, the fevers for which no organic lesion had been found. Essential fevers were subject to nosological classifications based on symptoms. They were thus distributed in two groups, the continuous and the periodic fevers: typhoid fever was placed in the first group. The climatic determinism and miasmatic theory approach to the study of these fevers in Colombia implied that they were produced under the specific conditions of each locale. These conceptual models were well-suited to the interest in constructing a national medical tradition based on the particularities of the local environment. Doctors could eventually claim, based on the specificity of local climate, to be capable of producing original knowledge about diseases. Colombian doctors were thus able to question European ideas regarding fevers. They argued that direct contact with diseases in the locale where they were produced was the basis of accurate knowledge about them. ${ }^{12}$ Such claims regarding typhoid fevers

\footnotetext{
${ }^{9}$ Antonio Vargas, 'Mis observaciones sobre la fiebre thyfoides', El Tiempo, No. 13, marzo 17 de 1855 and No. 14, abril 3 de 1855 (pages not numbered).

10 'Extracto de las actas de la Sociedad de Medicina', Revista Médica, 1, 1 (1873), 1; Humberto Cáceres and Zoilo Cuéllar-Montoya, Academia Nacional de Medicina de Colombia: Sus Miembros 1873-1997 (Bogotá: Academia Nacional de Medicina, 1998), 1-18.

${ }^{11}$ Claudia Mónica García, 'Las 'fiebres del Magdalena': Medicina y sociedad en la construcción de una noción médica colombiana, 1859-1886', Historia, Ciências, Saúde-Manguinhos (Rio de Janeiro) 14, 1, ene.-mar (2007): $81-5$.

12 An analysis of this attitude in the case of periodic fevers is found in García, "Las "fiebres del Magdalena" (n. 11). See also Stefan Pohl-Valero and Mónica García, 'Entre la ciencia del viajero naturalista y la ciencia de laboratorio: epistemologías de la naturaleza, el cuerpo y la sociedad en Colombia en el siglo XIX', working paper presented at the Coloquio de la Escuela de Ciencias Humanas, Universidad del Rosario (Bogotá), 27 February 2012.
} 
developed fully in the 1860s. Nonetheless, before we examine how Colombian doctors put forward such arguments, it is important to explore how mid-century accounts of the fever made it possible for doctors to advance towards the idea of typhoid fever as a distinct disease that was caused by miasmas.

During the 1855 epidemic of fevers in Bogotá (for which we have no statistical data), Vargas identified the fevers as typhoid fever, or the gastroenteritis of the French. Like French doctors, Vargas considered it to be the same as the typhus of the English. He speculated that typhoid fever was an eruptive disease like smallpox and therefore contagious: 'typhoid fever, like smallpox and measles, has invasive symptoms ... periods of eruption, suppuration and descamation'. These symptoms followed 'the pink spots, petechias, and the swelling, suppuration and ulceration of the Peyer patches'. ${ }^{13}$ Since the seventeenth century, doctors in Europe had been able to classify typhoid fever among the 'exanthemata'. They used the analogy between pox and the lesions of the ileum found in the case of this fever, an idea that was ratified by Pierre Bretonneau in 1829. Later on, during the early 1850s, the French Academy debated whether enteric fever was just an internal variola; in the early 1870s the Englishman William Budd also saw a true exanthema in the lesions of the Peyer patches by analogy with smallpox. ${ }^{14}$ Vargas classified typhoid fever as an eruptive disease as well, based not only on the similar course of symptoms mentioned above but also arguing that eruption in typhoid fever is less intense than in smallpox because 'in compensation, the inflammation of intestines is more intense' 15

Despite the initial entanglement of typhoid fevers with the exanthemata or eruptive fevers, Vargas would later separate typhoid fever from this group. In his 1862 nosology of fevers, where he firmly established that fevers consisted in two genres, the continuous and the periodic fevers, he also announced that the former encompassed two species: eruptive fevers (smallpox, measles, scarlet fever) and typhoid fevers (inflammatory, ataxic and adynamic fevers). At the same time Vargas recognised another new group, the typhus of the British as distinguished from typhoid fever. ${ }^{16}$ Thus, by placing typhoid fever in a separate group from the eruptive fevers and typhus, Vargas not only contributed to the increasing differentiation of typhoid fever; he was also able to point out a cause of typhoid fever different from the contagion of the eruptive fevers, the miasma.

By the time of the 1855 epidemic in Bogotá, doctors had consolidated the neoHippocratic scheme of specific, predisposing and occasional causes in which miasmas played a central role. Indeed, the search for a specific cause of typhoid fever was considered impractical at that time, so the focus was placed on what physicians considered to be the main predisposing cause, the miasma. This substance was supposed to debilitate the organism and make it susceptible to the fever, although occasional causes were also considered to be involved (for example, hot or cold air, winds, suppression of natural evacuations and moral emotions). ${ }^{17}$ The miasma that caused typhoid fever was supposed to be produced under specific circumstances: 'typhoid fever develops in besieged cities,

\footnotetext{
13 Vargas Reyes, op. cit. (note 9).

14 Stevenson, op. cit. (note 4).

15 Vargas Reyes, op. cit. (note 9).

16 Antonio Vargas, 'Discusión sobre la fiebre amarilla', Trabajos Cientí ficos del Doctor Antonio Vargas Reyes recopilados en obsequio de la humanidad doliente i de la juventud estudiosa de Colombia. Tomo Segundo [Vol. 2] (Bogotá: Imprenta la Nación, 1862), 54.

17 Vargas, op. cit. (note 9).
} 
in prisons and camps - that is, places where people accumulated, and where there was decomposing animal matter'. ${ }^{18}$

Thus, by 1860 Colombian doctors had not only identified the continuous fevers appearing in the highlands, specifically in Bogotá, as typhoid fever: they had also separated it from the other continuous fevers, eruptive fevers and typhus, and had highlighted its miasmatic origin. Between 1860 and 1880 considerations about typhoid fever would become intimately entangled with debates concerning the other genre of fevers, the periodic fevers, but also with the climatic determinism of diseases, medical geography and the project of constructing a national medical tradition.

\section{Medical Geography and Typhoid Fever 1860-1870}

Medical geography of the nineteenth century asserted an intimate relationship between diseases and geography. Medical geographers studied the geographical distribution of diseases assuming that illnesses, like plants, were distributed according to the climatic and geographical characteristics of the places where they developed. In its purest version, it claimed that diseases had a functional relationship with altitude and latitude. ${ }^{19}$ Following a similar argument, Colombian physicians from the 1860s onwards claimed, for example, that the warm lowlands of the riverbanks and seashores were causally associated with the occurrence of some periodic fevers. One of them was the yellow-fever variety of the Magdalena fevers. ${ }^{20}$ During the 1860 s doctors actually focused on the endemic and epidemic periodic fevers appearing along the Magdalena River Valley. The Magdalena River runs between the central and eastern branches of the Andes, connecting the heart of the country and Bogotá, which is located in the eastern branch of the mountains, with the rest of the world. The valley became an important area for agricultural production of tobacco for export by the middle of the nineteenth century. Doctors turned their attention to the epidemics that had been happening since $1857 / 8$ in villages where tobacco production was being stockpiled and exported. They even constructed a notion of 'Magdalena fevers', following the medico-geographical framework that was explained as fevers produced by miasmas associated with agricultural production. In particular, Magdalena fevers were supposed to have resulted from the action of heat and humidity typical of warm lowlands on organic matter. This matter could originate in the removal of soil, or in the accumulation of tobacco leaves or the residuums of the leather in which the tobacco was wrapped.

The economic importance of the tobacco-producing areas and the fear that periodic fevers like Magdalena fevers might appear in the highlands were the arguments doctors used to justify their project of building a national medical tradition. This project, prompted by the quest for legitimation of the medical profession, was to be created (a) on the basis of a 'corpus of doctrine' based on the study of local pathologies in accordance with medical geography; (b) on the basis of the creation of medical journals (1852, 1864 and 1873) and medical associations (1873) where doctors would share knowledge; and (c) on the basis of permanent medical training (1868). Magdalena fevers complied with the first condition. Physicians found in these fevers the possibility of emphasising the local origin of pathologies. More interestingly, physicians saw in the study of Magdalena fevers the opportunity to produce knowledge that would eventually contest European knowledge

\footnotetext{
18 Vargas, op. cit. (note 16), 40; similar views appeared in Antonio Vargas Reyes, 'Señor doctor Eloy Ordóñez: - Paris'. Gaceta Médica, 1, 4 (1865), 14.

${ }^{19}$ Nicolaas A. Rupke (ed.) 'Medical geography in historical perspective', in Medical History, Supplement No. 20 (London: The Wellcome Trust Centre for the History of Medicine at UCL, 2000).

${ }^{20}$ Garcia, op. cit. (note 11).
} 
and grant them the sort of national (and international) legitimacy that they lacked at that time. Doctors claimed that since they had direct experience of these periodic fevers in their natural place of occurrence, they were better qualified than Europeans to produce original knowledge about them. During the 1860s Colombian doctors supported the idea that typhoid fever 'shows a peculiar character in Colombia with regards to aetiology, age and climate'. ${ }^{21}$ Their references were to French ideas regarding the fever. Antonio Vargas and Abraham Aparicio, one of the founders of the SMCN, argued that while French authors described typhoid as rarely occurring among individuals over the age of forty, their own experience in Colombia contradicted that conclusion. Through autopsies, Vargas was said to have found typhoid fever in people of all ages. ${ }^{22}$ Andres Posada, from the province of Antioquia made similar claims. Manuel Vicente de la Roche, moreover, insisted that Pierre A. Louis's principle that typhoid does not occur in individuals over sixty did not coincide with what he had seen in Colombia. ${ }^{23}$

A peculiarity of typhoid fever in Colombia, highlighted by physicians, was the role of climatic or local conditions. According to the French, changes in climate and habits would account for the higher susceptibility to contracting typhoid amongst foreigners. Vargas said that the opposite was true in Colombia: local people were the main victims of typhoid in Bogotá, whereas foreigners were rarely affected. ${ }^{24}$ Most importantly, the peculiarity of typhoid fever in Colombia, according to doctors, related to its lack of geographical determinism. Indeed, unlike periodic fevers, which physicians strongly associated with climate, physicians classified typhoid fevers amongst the continuous and eruptive fevers, a group which did not appear to them to be essentially determined by climate. Furthermore, they claimed to have found typhoid fever all over the country regardless of the geographical settings. Nevertheless, these facts did not imply that doctors could not argue in favour of local particularities of typhoid fever in Colombia or even contest European knowledge about it. On the contrary, they used the ideas of the French medico-geographer Jean-Christian Boudin to make such claims. Boudin had stated that where intermittent fevers occurred (e.g., in swamps), typhoid fever was scarce. This was because of what Boudin called the laws of geographical distribution of diseases. In his 1843 Essai de Géographie médicale, Boudin explains these laws:

We would name as the law of geographical affinity or coincidence the situation in which two morbid forms are endemic in one locality and occur either in parallel or consecutively. We would name as the law of geographical antagonism ... the situation in which some pathologies do not occur in the same locality because of their own endemic characteristics. ${ }^{25}$

The more one finds an endemic disease in a particular place, the more likely one is to find related diseases and the less likely to find antagonistic ones. The overlapping occurrence of yellow fever, cholera and plague would be an example of the law of geographic coincidence, while swamp fever, tuberculosis and typhoid fever would be an example of the law of geographic antagonism. ${ }^{26}$ The evidence that Boudin presented

21 Vargas, op. cit. (note 16), 13.

22 Ibid., 13.

${ }^{23}$ Andres Posada, 'La fiebre tiofidea en Medellín', Gaceta Médica, 1, 10 (1866), 39.

24 Vargas, op. cit. (note 16), 13.

25 Jean Christian M. Boudin, Essai de géographie médicale, ou, Études sur les lois qui président a la distribution géographique des maladies, ainsi qu'à leurs rapports topographiques entre elles: Lois de coüncidence et d'antagonisme (Paris: Germer-Bailliére/Ladé, 1843), 76-7.

${ }^{26}$ Brunache, 'Recherches sur la phtisie pulmonaire et la fièvre typhoïde considérées dans leurs rapports avec les localités marécageuses', in J. Ch. M. Boudin (ed.), Études de géographie médicale: Notamment sur la question de l'antagonisme pathologique (Paris: J.-B. Baillière, 1846), 21-2. 
for the antagonism between intermittent and typhoid fevers came from the experience of French military expeditions:

If we consider that M Roux, head of the medical expedition to Morea, does not mention anything about it [typhoid fever], one can conclude that dothiénenterie [or typhoid fever] is extremely rare in localities where swamp fevers occur. This opinion, based on observations in Africa and on careful examinations of thousands of people evacuated from Morea, Algeria and Senegal to France, seems to authorise us to convert this opinion into law. ${ }^{27}$

For the Colombian doctors Vargas and Posada, Boudin's law of antagonism between swamp fever and typhoid fever was not applicable in Colombia. According to Vargas, typhoid fever 'goes hand in hand with periodic fevers'. Furthermore, he affirmed that the fever was not determined by climate:

Typhoid fever has become generalised in the República and climate does not have any influence in its production; because it is as common in this savannah, where temperatures are cold, as it is in the Cauca and Antioquia provinces, of a temperate climate, and the Coasts and the Magdalena, of a burning climate. ${ }^{28}$

Observation by Colombian physicians living in other regions of the country added to the argument against Boudin's law of antagonism between typhoid and swamp fevers. Andrés Posada argued that in rural areas surrounding the city of Medellín the malarial influence was strong and typhoid fever was also endemic. When both fevers occurred simultaneously in one person, he said, the fever took the form of remittent fever. Thus, Posada concluded, Boudin's 'geographical antagonism does not exist in Colombia'. ${ }^{29}$

Colombian physicians used the debates regarding typhoid fever in the 1860 s to emphasise their own ability to produce original knowledge and contest European notions about typhoid fever. Doctors contested European knowledge of typhoid fever by arguing their own experience against the medico-geographical laws of Boudin, an important stage in the Colombian medical project.

\section{Typhoid Fever and Periodic Fevers in Bogotá in the 1870s}

The debates regarding the supposed medico-geographical antagonism between typhoid and periodic fevers continued throughout the 1870s and early 1880s in the recently created Sociedad de Medicina y Ciencias Naturales (SMCN, 1873). The creation of the SMCN soon after the establishment of a permanent medical training program in 1868 in the Universidad Nacional in Bogotá, was one step forward in consolidating the doctors' project of constructing a national tradition of medicine. The SMCN became a place where doctors could share and debate their clinical experience, a site of contentious creation of knowledge. Between 1874 and 1878 medical elites gathered around the society continued to emphasise the differences between local and European typhoid fevers, but they also voiced their concerns about the possibility of typhoid fever occurring in the highlands alongside the dreadful periodic fevers typical of the warm lowlands. So important were considerations of medical geography and the fear of periodic fevers occurring in Bogotá that debates about the nature of typhoid fevers in the highlands continued to revolve around periodic fevers.

\footnotetext{
27 Boudin, op. cit. (note 25), 20.

28 Vargas, op. cit. (note 16), 13.

${ }^{29}$ Posada, op. cit. (note 23), 39.
} 
In May 1874, Policarpo Pizarro and Abraham Aparicio presented before the SMCN the bizarre case of a 22-year-old man diagnosed as having a bilious form of typhoid fever. ${ }^{30}$ Since the symptoms worsened after a short relapse, Pizarro and Aparicio diagnosed it as a case of remittent fever of pernicious character and treated the patient with quinine sulphate, only to find him dead. ${ }^{31}$ Both doctors considered this case of interest for the SMCN because it contradicted Boudin's law of antagonism:

We were very surprised with this case ... because it consisted of two fevers occurring consecutively in one person and some authors consider that these fevers exclude each other. This truth [of antagonism between intermittent and typhoid fever] proclaimed by M Boudin as demonstrated by experience, would have led him to argue that the longer and more sustained the miasma action, the stronger the typhoid fever. Our case contradicts this appreciation. ${ }^{32}$

By displacing the context of Boudin's law of antagonism from the marshy lowlands of the French colonies to the highlands of the Colombian Andes, Aparicio and Pizarro declared that Boudin's law of antagonism was false. ${ }^{33}$

Pizarro's and Aparicio's diagnosis was opposed by some members of the medical society. Proto Gómez and Rafael Rocha, both of whom had also graduated from the Medical School of Paris, believed that it was not a case of typhoid followed by a remittent fever, but one of typhoid with recrudescence. Gómez argued that the failure of quinine to cure the remittent fever was proof enough to conclude that the patient had never suffered such a disease. ${ }^{34}$ Rocha agreed with this inference and considered that typhoid fever was frequently both preceded and followed by intermittency which had nothing to do with the paludic (malarial) infection or deleterious actions of effluvia. ${ }^{35}$ Pizarro's and Aparicio's diagnosis was supported by only one member of the SMCN, Manuel Plata, who had also trained in Bogotá and Paris. Plata actually saw in the case of this young man an illustration of the fact that pernicious fevers could indeed occur in the highlands. In his view, the case was one of typhoid followed by 'cerebral paludic fever'. He also discredited the argument about quinine, for if quinine failed to treat the intermittent fever in the case discussed, it was not because the young man had not suffered intermittent fever, but because quinine was not an infallible and specific treatment for such a fever. In other words, the success or failure of quinine did not have diagnostic value. ${ }^{36}$ The members of the SMCN were divided in their opinions about the nature of typhoid fever in Bogotá, so the problem remained unresolved.

In the following years, some physicians introduced a new element into the debate - clinical thermometry. Karl Wunderlich, the founder of this method, had published his famous monograph on clinical thermometry in 1871, which included twenty years of research into temperature and fever in Leipzig. ${ }^{37}$ It is difficult to say when clinical thermometry was first introduced in Colombia, but there is evidence that it was a common

\footnotetext{
${ }^{30}$ P. Pizarro and A. Aparicio, 'Observación de los señores doctores Aparicio y Pizarro', Revista Médica, 2, 15 (1874), 123.

${ }^{31}$ Sociedad de Medicina y Ciencias Naturales (SMCN), 'Sesión del día 9 de mayo', Revista Médica, 2, 19 (1874), 131.

32 Pizarro and Aparicio, op. cit. (note 30), 123-4.

33 SMCN, op. cit. (note 31), 133.

${ }^{34}$ Proto Gómez, 'Señores miembros de la Sociedad de Medicina de Bogotá', Revista Médica, Serie II, No. 15, 18 de julio, 1874, 124-5.

35 SMCN, op. cit. (note 31), 131-2.

36 Ibid., 133.

${ }^{37}$ Smith, op. cit. (note 4), 294-6.
} 
practice in the wards of the San Juan de Dios university hospital in Bogotá by $1877 .{ }^{38}$ Clinical thermometry reinforced in the minds of Colombian doctors the idea that typhoid and typhus were two different diseases. Thermometry also represented another criterion for differentiating what doctors now began to call paludism, typhoid fever and typhus. According to Osorio:

Thermometry would give us a new sign that would differentiate between dotinenteria [or typhoid fever] and typhus fever, as well as provide a new way to demonstrate the diversity of fevers that could exist in a locality. That method would reduce any bias derived from the theoretical choices of the observer ... Thermometric lines in paludic, typhoid and typhus fever are different. ${ }^{39}$

Despite this strong argument from a prominent figure within the SMCN - that thermometry helps to clarify the diagnosis of fevers - this method did not help to establish whether paludic fevers occurred in the highlands Nor was the periodicity of typhoid fever as measured by the thermometer equated either to paludism or to a miasmatic cause. ${ }^{40}$ Interestingly, physicians in other regions applied clinical thermometry to attack Boudin's law of geographical antagonism between malarial and typhoid fever. Thermometry became one method used by some doctors in their continuous effort to illustrate the particularity of local diseases and the value of their claims to knowledge. For example, José Tomás Henao, trained in Bogotá and Paris, treated a 44-year-old doctor in the village of Sonson (a temperate-climate rural community in the province of Antioquia), who had both remittent pernicious fever and typhoid fever. Henao diagnosed the latter, by exclusion, on the basis of Wunderlich's axioms: 'any disease that has not reached $39.5^{\circ} \mathrm{C}$ by the afternoon of the fourth day is not typhoid fever' and 'any disease that reaches a temperature of $40^{\circ} \mathrm{C}$ on the first or second day is not typhoid fever'. For Henao, this case illustrated that typhoid and pernicious fevers could both be present at the same time. It convinced him of what elite doctors already believed: that Boudin's law of geographic antagonism between these two fevers did not apply in Colombia. ${ }^{41}$

By the end of the 1870s the Colombian medical elite still debated whether typhoid fever could occur alongside periodic paludic fevers or even whether it was in itself a paludic fever, so much so that doctors created a new category to deal with them, the typhoid bilious remittent fever.

\section{The Typhoid Bilious Remittent Fever}

In 1878, physician Rafael Rocha reported before the SMCN on the existence of possible cases of typhoid fever in Bogotá. ${ }^{42}$ However, after a close analysis he ruled out this diagnosis and presented them as one kind of periodic fever, the remittent fever of warm climates. Other physicians claimed to have seen similar cases. Pio Renjifo believed that it was not just the bilious remittent fever of warm climates but 'the intermittent fevers of the kind that from the pathological point of view we could reasonably believe to be

\footnotetext{
38 Abraham Aparicio, 'Los baños fríos en el tratamiento de la fiebre tifoidea', Revista Médica, Serie 4, 42 (1877), 343-6.

${ }^{39}$ Nicolás Osorio, 'Trazados termométricos de la fiebre tifoidea (dotinenteria) y del typhus fever (tifoexantemático): Diferencia de estos trazados', Revista Médica, 43 (1878), 351-3.

${ }^{40}$ Evaristo Garcia, '[Carta a la Revista Médica, Paris, abril 7 de 1876]', Revista Médica, 4, 38 (1876), 315; Aparicio, op. cit. (note 38), 345.

41 José Tomás Henao, 'Observación de una fiebre tifoidea seguida de remitente perniciosa de forma diaforética', Revista Médica, 4, 47 (1878), 386-7; Ibid., 4, 48 (1878), 395-7.

42 Abraham Aparicio, 'Sociedad de Medicina: Sesión del día 4', Revista Médica, 5, 49 (1878), 411.
} 
found in the riverbanks of the Magdalena River' ${ }^{43}$ Insofar as the diagnosis of fevers was based on symptoms, both diagnoses could be considered plausible. Liborio Zerda, physician and professor of natural sciences, argued that Bogotá's geological constitution favoured putrefaction, which he equated to fermentation. Hence, the city would have been periodically producing miasmas that infected the atmosphere and produced typhoid fever and intermittent fevers. ${ }^{44}$ As an epidemic of fevers occurred in Bogotá and nearby villages, in 1881, doctors proposed a new encompassing category that embraced the 'typhoid' and 'paludic' elements in one category: typhoid remittent bilious fever. ${ }^{45}$

Indeed, the SMCN envoy who studied the epidemic, Alberto de J. Roca, reported in 1882 that the 1881 epidemic was one of typhoid bilious remittent fever, apparently without using a thermometer or performing any autopsy. He was sure of the diagnosis because 'if, like the majority of physicians, we believe that this is a typhoid bilious remittent fever, all cases must have the same intestinal alterations typical of that disease'. ${ }^{46}$ Roca assumed that this typhoid fever was associated with filth and that it may have been associated with a paludic element. He placed typhoid fever alongside the bilious remittent fever of warm countries, thus taking it out of the group of continuous fevers and placing it in the periodic group. He did not discard the possibility that typhoid and the 'true intermittent fevers' or paludic fevers could develop simultaneously or consecutively in the city. ${ }^{47}$ The new category of typhoid bilious remittent fever condensed ten years of debates among Bogotá's medical elites regarding the double nature of the fevers of the city, typhoid and paludic kinds. It is at this point that physicians who defended the novel Pasteurian notions would enter the scene.

By mid-century Colombian doctors had defined typhoid fever as a specific disease amongst the continuous fevers, different from the other exanthematic fevers and even typhus fever. In the 1860s, they began to emphasise the particularities of typhoid fever in Colombia in accordance with their project of constructing a national medical tradition based on their own direct experience with the fevers. This occurred parallel to their effort to establish the institutional basis with which to gain authority both nationally and internationally by creating a medical journal and association and as well as stable medical training. Although typhoid fever was not defined as functionally dependent on climate as the periodic fevers of the Magdalena valley, the fear of intermittent periodic fevers like those of the Magdalena developing in the highlands would explain why doctors debated the topic of typhoid fever within the framework of medical geography, particularly with respect to the laws of Boudin. In so far as typhoid fever continued to be distinguished by symptoms, debates on their simultaneity or the mixed nature of typhoid and paludic fevers were frequent. Physicians even proposed a new intermediate category, the typhoid remittent bilious fevers. Although thermometry was probably introduced in the late $1870 \mathrm{~s}$ and some doctors thought it would help to distinguish between paludic typhoid fever and typhus, it did not have any great impact in the controversies regarding the identity of typhoid fever. The introduction of bacteriology in the 1880s altered the medical dialogue.

\footnotetext{
43 Ibid., 411.

44 Ibid., 412.

45 By the mid-nineteenth century, North American physicians had also created a category that mixed typhoid and malarial fever, the typhomalarian fever, for the fevers typical of the region to the south of the Mason-Dixon Line. This fever continued to be diagnosed and studied well into the twentieth century, between the American Civil War and World War I. See Smith, op. cit. (note 4).

${ }^{46}$ Roca, op. cit. (note 1), 146-7.

47 Ibid., 148-51.
} 


\section{Germ Theory in the Typhoid and Paludic Fever Controversy in Bogotá in the $1880 \mathrm{~s}$}

In 1882, the SMCN commissioned one the earliest advocates of bacteriology in Colombia, Gabriel J. Castañeda, to study Roca's report on fevers in Bogotá and his diagnosis of typhoid bilious remittent fever. In contrast to the majority of his colleagues involved in the controversies regarding typhoid fever, Castañeda had never reached the medical international centre, Paris. He became the fiercest advocate of Pasteurism during the 1880s. Castañeda took the opportunity to campaign in favour of the new theory in his analysis of Roca's diagnosis of typhoid remittent fever. Indeed, Castañeda's report, published in 1883, revolved around germs as the cause of typhoid fever. ${ }^{48}$ He reminded the world of Edwin Klebs's work reproducing typhoid in rabbits, and his assertion that the microbe was found only in typhoid fever patients. ${ }^{49}$ In Castañeda's opinion, the 'panspermic theory' - that is, the Pasteurian germ theory - would come to clarify many controversial issues about the development of miasmatic diseases. ${ }^{50}$ Castañeda said little about Roca's diagnosis of typhoid bilious remittent fever. The society felt that Castañeda had missed the point of his commission. Nicolás Osorio, well aware of the Pasteurian germ theory, accused Castañeda of not having addressed key questions such as: 'Do palustre fevers exist in Bogotá? Could typhoid fever take the form of an intermittent fever? Is there any form of typhoid fever that is not produced by the miasma tifico? ${ }^{51}$ Osorio insisted that the main problem was not the identification of the cause of typhoid fever, as Castañeda had reported, and he took the opportunity to show his strong scepticism of Pasteurism. As far as Osorio was concerned, Pasteurians placed too much emphasis on antiseptic medication. Castañeda responded to this accusation by insisting that typhoid fever should be treated by antiseptic methods even though it had not been fully demonstrated that it was actually caused by bacteria. ${ }^{52}$

Abraham Aparicio championed bacteriology to explain the double nature of typhoid fever in Bogotá. In 1884 Aparicio, like Castañeda, welcomed bacteriology, arguing that 'pathology has found the explanation for many apparent disagreements with the clinic', referring to the nature of fevers in Bogota. ${ }^{53}$ Aparicio suggested that the variety of climates, temperatures, humidity and atmospheric pressures of the country explained why the atmosphere played a key role in the variety of diseases, for all those elements would

\footnotetext{
${ }^{48}$ Castañeda, op. cit. (note 2). By this time, the Revista Medica had been publishing extracts of debates in France about the novel cause that French doctors called the 'ferment' or 'microbe' and its possible route of transmission (mainly through the faeces of sick people). See: Avelino Saldarriaga, 'Epidemia de fiebre tifoidea en Paris', Revista Médica, 81 (1883), 395-6, and 'Etiología y tratamiendo de la fiebre tifoidea: Academia de Medicina de Paris: Sesiones del 7, 14, 21, 28 de noviembre y 5 y 12 de diciembre, 1882', Revista Médica, 82 (1883), 438, 441-3; Juan E. Manrique, 'Tratamiento de la fiebre tifoidea', Revista Médica, 83 (1883), 488.

49 The standard story is that in July 1880 , Carl Eberth published his discovery of short rodlike bacteria in the tissues of fatal typhoid cases. In 1881 Robert Koch published photomicrographs of rodlike bacteria from the tissue of fatal typhoid cases. Eberth and Klebs agreed that they and Koch had all seen the same organism. In 1881 Klebs reported that he had grown an organism in culture media that, when inoculated into laboratory animals, produced lesions. In 1884 Georg Gaffky was able to isolate the bacterium using gelatine culture media but was unable to produce evidence of disease when he injected the pure cultures into animals. Despite the failure to satisfy the 1882 criteria established by Koch, the rodlike bacterium - bacillus typhosus - became generally accepted as the causative organism of typhoid fever. See Smith, op. cit. (note 4), 299.

50 Castañeda, op. cit. (note 2), 84.

51 Ibid., 93.

52 Ibid., 94.

53 Abraham Aparicio, 'Discursos pronunciados en la sesión solemne del 27 de febrero de 1884', Revista Médica, 93 (1884), 377-8.
} 
influence the 'many germs which develop in it'. Germs in the atmosphere varied according to the environment and also according to the conditions of the organism, which was why (continued Aparicio) it was not surprising that 'two different germs develop in the same organism and therefore we would never again reject the idea that typhoid fevers could be followed by remittent pernicious fevers'. ${ }^{54}$ The germ theory was used here as an argument in favour of both fevers occurring in Bogotá.

Aparicio's idea that pernicious fevers were caused by germs and could therefore also be found alongside typhoid fevers in Bogotá signified a transition in Bogotá's scientific community. It is possible that the growing differentiation that doctors were simultaneously establishing between the endemic (paludic or malarial) fevers and the epidemic (yellow) fevers of the Magdalena River Valley, both typical of the lowlands, may have contributed to the decline of this debate. Paludic fevers will no longer be considered as one of the fevers of the highlands. The Pasteurian cause of typhoid fever, germs, proved to be a more controversial topic.

\section{Germs vs. the Spontaneous Origin of Typhoid Fever}

During the early 1890s Colombian physicians suggested alternatives to the theory of the germ identity of typhoid fever, including the spontaneous generation of the fever. The theory of spontaneous generation contradicted the core ideas of Pasteurism. Pasteurians believed the future of medicine depended on a life-and-death struggle against the traditional doctrine of the spontaneity of disease. ${ }^{55}$

In 1890 Ignacio Osorio, one of the supporters of the theory of spontaneous development of typhoid, claimed that typhoid fever was a putrid intoxication that originated within the body. ${ }^{56}$ Following the French author Sigismond Jaccoud in his Traite de Pathologie Interne (1871), Osorio argued that the organism contained poisonous putrid matter that is normally destroyed but which, when it is not destroyed, can become a source of the typhoid poison. In this case it could be said that typhoid fever was completely generated within and by the organism itself. The spontaneous generation of typhoid, the French author had said, should be admitted only by exclusion, when it was not imputable to another cause, but Ignacio Osorio did not recognise the subordination of the spontaneous origin of typhoid fever to any extrinsic origin. On the contrary, he attempted to compare Jaccoud's observations to the observations made in Colombia in order to support his own beliefs.

Osorio justified the spontaneous generation of typhoid fever within the framework of medical geographical arguments. Colombian doctors had rejected a climactic cause of typhoid fever. They contested Boudin's law of antagonism between typhoid and paludic fevers. Ignacio Osorio returned to a similar argument and argued that since 'abdominal tifus' developed on all continents, 'its cause must necessarily be in all places, in all countries, in almost all latitudes' ${ }^{57}$ If typhoid fever was determined neither by climate nor by any specific ferment, he wondered 'whether the cause lies in the human organisation that under certain circumstances awakes from its latent state and becomes visible' ${ }^{58}$ His

\footnotetext{
54 Ibid., 381-2.

55 Gerald Geison, 'Pasteur', in Charles Coulston Gillispie (ed.), Dictionary of Scientific Biography, Vols 9-10 (New York: Charles Scribner's Sons, 1981), 384.

56 Ignacio Osorio, 'Observaciones que pueden servir para elvol estudio de la causa o causas que generan la fiebre tifoidea', Revista Médica, 145 (1890), 742; S. Jaccoud, Traité de pathologie interne, Vol. 2 (Paris: Adrien de la Haye, 1871), 726-8.

57 Jaccoud, Traité, 742 .

58 Ibid., 742.
} 
observations of typhoid fever in Bogotá and lower down in the Magdalena River Valley, both in crowded and isolated places, proved to him that it was not caused by a germ but developed spontaneously in the body instead. ${ }^{59}$

One opinion supporting Ignacio Osorio's theory of the spontaneous generation of typhoid fever appeared in the Revista Médica. The opinion, written by an unknown author, was that typhoid was indeed caused by a germ but one that was produced spontaneously within the body. This could explain why typhoid fever was a cosmopolitan disease that " "develops with absolute exclusion of thermometer, barometer, hygrometer, and even pluviometer": its germs lived and grew everywhere, from the poles to the equator, and it occurred wherever humans were found, in crowded places as well as in isolated country houses, because the germ was produced spontaneously within the body'. ${ }^{60}$

These opinions produced a controversy among SMCN members that evidenced how Colombian physicians oscillated by 1890 between bacteriology and anti-Pasteurian arguments in their considerations of typhoid fever. Indeed, Castañeda, who originally proposed that the SMCN consider the germ cause of typhoid fever in 1883, attacked the spontaneous generation theory. In his 1890 paper about the aetiology and pathogenesis of typhoid fever, Castañeda argued that the theory of spontaneous generation of typhoid fever had been completely discredited by the development of experimental medicine. ${ }^{61} \mathrm{He}$ asserted that science had demonstrated the existence of the Eberth bacillus microbe, which was considered to be the specific cause of typhoid fever. Castañeda said typhoid could happen anywhere, whether it was isolated or crowded, because microbes could resist both high and low temperatures and could maintain their noxious properties for long periods of time. His perspective thus contradicted every point made by those arguing in favour of the spontaneous generation of typhoid fever. For Castañeda, there was no evidence to support the spontaneous generation doctrine. ${ }^{62}$

Despite Castañeda's opinion in favour of the germ doctrine regarding typhoid fever, Colombian physicians resisted bacteriology as the first line of explanation of the fever. Even one of the converts to Pasteurism supported a more sophisticated version of the spontaneous origin of typhoid. In 1884, Aparicio had provided a provisional closure to the debate over the possibility of paludic and typhoid fever in Bogotá, arguing that both were caused by germs and therefore both could occur in the city. However, when Aparicio intervened in the debate regarding the spontaneous origin of typhoid fever in $1890,{ }^{63}$ he followed Peter, a professor of internal medicine at the Charité Hospital in Paris and Pasteur's well-known challenger in the Academy of Medicine. ${ }^{64}$ According to Peter, 'the majority of fevers are the result of the exaggeration or deviation of our functional acts'. ${ }^{65}$ Peter explained that after hard work - be it physical, moral or intellectual - the body could develop a 'typhic-like' fever when natural inorganic products were eliminated incompletely. The aforesaid fever could become epidemic and develop into the true "typhus".' Peter called this 'auto-typhisisation'. Aparicio, believed that this was plausible:

${ }^{59}$ Ibid., 743-6.

60 'Crónica', Revista Médica, 151 (1890), 123.

${ }^{61}$ Gabriel J. Castañeda, 'Etiología y patogenia de la fiebre tifoidea', Revista Médica, 152 (1890), 129.

${ }^{62}$ Ibid., 130-2.

63 Abraham Aparicio, 'Auto-tifisasión espontánea', Revista Médica, 152 (1890), 133-7.

${ }^{64}$ Anne Marie Moulin, 'Bacteriological research and medical practice in and out of the Pasteurian school' in Ann La Berge and Mordechai Feingold (eds), French Medical Culture in the Nineteenth Century (Amsterdam/Atlanta, GA: Editions Rodopi, 1994), 328.

${ }^{65}$ Aparicio, op. cit. (note 63), 133. 
'it is therefore not surprising that we lack faith in the idea that the Eberth bacillus is the specific agent of typhoid fever in contrast to the thorough acceptance of this idea by Castañeda' ${ }^{66}$

Aparicio suggested that some physicians in Colombia did not follow what he called the 'exclusivist approach' or the reductionism of bacteriology in their clinical practice. These sceptics believed that the new discoveries - ie. the Pasteurian germ theory - could not stand by themselves as scientifically valuable; they needed to be related to the 'traditional' clinical medicine. It was there, at the bedside, that truth and progress must be sought, he said. ${ }^{67}$ Aparicio aligned himself with those sceptics who accepted bacteriology only to a certain extent and simultaneously defended the theory of spontaneous origin of typhoid fever. In his view, the sanction of discovery of the bacillus, based on experimental and anatomopathological verifications, could not be used to deny the spontaneous morbidity of the organism to catch diseases (or, as Peter said, the capacity of the organism to create its own microbes). ${ }^{68}$

Germ theory proved contentious among the Colombian medical elite. Why? Taking the case of Aparicio and Castañeda, representatives of anti-Pasteurianism and Pasteurism respectively, both physicians were trained at about the same time and in the same school of thought: Castañeda had graduated in 1867 from the private medical school which was the basis of the medical school of the new Universidad Nacional in Bogotá (1868) from which Aparicio graduated in $1871 .^{69}$ Differences in their arguments might have to do with the extent to which each was involved in the medico-geographical era. Aparicio had been active in debates during the 1870s in which typhoid fever was discussed in medico-geographical arguments. This might have made him suspicious of the promises of Pasteurism. In contrast, Castañeda had never participated in those debates nor did he seem to have used medical geography in his works. He always defended Pasteurism, at least from 1882 onwards.

\section{Typhoid Fever and Bacteriology 1887-1897}

While doctors were raising anti-Pasteurian arguments regarding typhoid fever by 1890 , antiseptic and bacteriological principles had already been shaping clinical and hygienic practices. This was evident during the epidemics in Bogotá beginning in 1887 when Bogotá's increasing demographic density aggravated the city's poor hygienic conditions. Historians have described how Bogotá had suffered a slow population growth throughout the 1860 s, followed by significant demographic expansion in the 1870s and 1880s that marked the emergence of the modern city. ${ }^{70}$ According to different scholars, the strained population density caused by this growth, in combination with limited sanitation and sewage facilities, had been blamed for the sharp rise in infant mortality and disease during the final decades of the century. ${ }^{71}$ Some historians have pointed to the 1890 s as the decade

\footnotetext{
66 Ibid., 134.

67 Ibid., 135.

68 Ibid., 136-7.

${ }^{69}$ Cáceres and Cuellar, op. cit. (note 10), 1, 21.

${ }^{70}$ For an analysis of scholars debate on this estimates see David Sowell, 'Population Growth in Late-NineteenthCentury Bogotá: Insights on a Demographic Dilema', Journal of Urban History, 38, 4 (2012), 720-30. See also Constanza Castro, '... que no hay gobierno sin cooperación científica': 'Urbanization, Medical Practices and State Formation at the End of the Nineteenth Century', manuscript.

71 Germán Rodrigo Mejía Pavony, Los años del cambio: Historia urbana de Bogotá, 1820-1910, (Bogotá, CEJA; 2000), 298-9; 358-9.
} 
with the highest mortality rates during the entire century, and typhoid fever undoubtedly contributed to a certain extent. ${ }^{72}$

The 1887 epidemic was denounced before the recently created Junta Central de Higiene-JCH (Central Hygiene Bureau) by the mayor of Bogotá, Higinio Cualla, in September of that year. This bureau was an official institution formed by members of the SMCN, an indication of how successful doctors had been in gaining social recognition at the national level. The local administration of Bogotá, which had been taking measures on its own to tackle the epidemic, reported an increase in the number of cases of typhoid fever at San Juan de Dios Hospital to the JCH. The mayor ordered police inspectors to improve the cleaning of city streets and the disposal of rubbish since he was convinced that filth, faeces and garbage were closely associated with any epidemic in the city. Nevertheless, Cualla ultimately blamed San Juan de Dios Hospital, where medical students of the Universidad Nacional received their training, for the increased 'typhus' death toll (fourteen out of twenty-two victims died in that hospital). Cualla denounced the lack of disinfection in the hospital wards and the fact that corpses were left in the anatomy amphitheatre for several days. ${ }^{73}$ The anatomy professors responded to Cualla's accusations by claiming that they did not dissect the corpses of those who died of dysentery, typhoid or any other contagious diseases ${ }^{74}$ and that the wards in the hospitals were in fact disinfected. Josué Gomez, who had also studied in the Medical School of Paris, remembered that all chamber pots were washed with iron sulphate and that beds were cleaned with carbolic acid once they became vacant. ${ }^{75}$ These practices were based on the germ theory perspective. The use of antiseptic substances for disinfection for faeces, which were considered the main route for transmission of the typhoid fever germ at that time, seems to have been introduced in Colombia after Pasteurism. Besides, the earliest use of Listerian practices concurred with the introduction of the germ theory of human diseases. ${ }^{76} \mathrm{JCH}$ members recommended a similar approach to that being used in the hospital to the mayor of the city in order to halt the transmission of typhoid. Not only were public latrines needed for those who lacked sewage systems; it was also necessary to make disinfection with carbolic acid for typhoid victims' faeces compulsory, doctors claimed. ${ }^{77}$

These hygienic measures, like those taken in the hospital, were justified by bacteriological principles of disinfection, as mentioned above. The demographic transformation of the city and the newly-created public health institutions undoubtedly contributed to the introduction of these practices with respect to the fever. Nonetheless, in the realm of causal speculations, and parallel to the debate on the spontaneous origin of typhoid fever analysed in the previous section, physicians and members of the JCH mixed the old miasma terminology with germ terminology up until the end of the century. An example of the miasmatic terminology is the JCH claim in 1888 that 'the city is under the influence of typhoid miasmas and others of exceptional gravity'. ${ }^{78}$ Furthermore, Jorge

\footnotetext{
72 Castro, op. cit. (note 70), 2.

73 Junta de Higiene, 'Sesión del día 28 de noviembre de 1887', Revista de Higiene, 6 (1888), 124-5.

74 Junta Central de Higiene, 'Continúa. Sesión del día 5 de diciembre de 1887', Revista de Higiene, 7 (1888), $131-2$.

75 Junta Central de Higiene, 'Sesión del día 5 de diciembre de 1887', Revista de Higiene, 6 (1888), 127-9.

${ }^{76}$ Emilio Quevedo et al., Historia de la Medicina en Colombia, Tomo III: Hacia una profesión liberal (1865-1918) (Bogotá: Tecnoquímicas, 2013), 105.

77 Junta Central de Higiene, 'Sesión del $1^{\circ}$ de octubre de 1887', Revista de Higiene, 1, 5 (1888), 95-8.

78 Junta Central de Higiene, 'Sesión del día 23 de abril de 1888', Revista de Higiene, 7 (1888), 160-1. In the same year, however, the Revista Médica published a summary of the bacteriology of typhoid fever. The summary
} 
Boshell's 1889 thesis on the continuous fevers in San Juan de Dios Hospital argued that 'Everybody knows that the fever originated in the emanations awoken by the removal of land during the construction of sewers', from where it spread by infecto-contagion and inoculation. ${ }^{79}$

References to germs were clearer in medical accounts after 1889 as an increased number of cases of fevers occurred in Bogotá. ${ }^{80}$ Castañeda, who had first suggested in 1883 that typhoid was caused by a germ in 1883 , found no opposition this time. ${ }^{81}$ Nicolás Osorio - and Proto Gómez - supported Castañeda's germ hypothesis: if not produced by the putrefaction of filth, they argued, the typhoid fever germ could have been spread by milk contaminated with impure water or by bad meat, ${ }^{82}$ leather deposits, slaughterhouses and filth deposits. ${ }^{83}$ However, when a second notable increase in the number of cases of typhoid occurred in Bogotá $1897,{ }^{84}$ the miasmatic language used to refer to the causes of typhoid fever resurfaced. Physicians and members of the $\mathrm{JCH}$, who were already convinced of the germ cause of the fever, continued to mix germ terminology with miasmatic dynamics, considering germs to be spread by air. For example, Pablo García Medina, who was studying medicine in Bogotá when Pasteurian ideas began to be debated, explained that:

It is an undeniable fact that gases that escape from those holes [sewers] can cause infectious diseases. They carry microbes that produce those diseases which are then deposited in the soil from where they could be transported by air. So, we absorb the microbe of typhoid fever, for example, not only from the water we drink but also from the air we breathe. ${ }^{85}$

When the bacteriological hypothesis regarding typhoid fever was first introduced in the early 1880s, physicians reacted against it and some even raised anti-Pasteurian arguments insisting on the spontaneous generation of the fever. They denounced the exclusivist approach of bacteriology, highlighting its subordination to medicine. Doctors continued to use miasma terminology to deal with typhoid fever up until the end of the century although from the late 1880s antiseptic measures became consolidated in clinical and hygienic practices as tools with which to tackle the epidemics of a city with increased demographic density. These practices announced an inexorable change in the debates about typhoid fever in comparison with the medico-geographical era. By the 1890s the medical elites had crystallised their efforts to consolidate the medical profession and had managed to secure permanent medical training, create journals and form associations in several cities. ${ }^{86}$ They even managed to establish an official national hygiene board, the JCH. This meant that

offered information on Eberth and Kleb's typhoid bacillus and their findings from autopsies of dotinentéricos, concluding that 'the specific and pathogenic role of the Eberth bacillus is firmly established'. See 'El bacilo de la fiebre tifoidea', Revista Médica, 123 (1888), 1044-53.

79 Jorge Boshell, 'La fiebre contínua del hospital de San Juan de Dios', Tesis para el doctorado en Medicina y Cirugía (Bogotá: Imprenta Echeverría, 1889), 10.

${ }^{80}$ Junta Central de Higiene, 'Sesión del dia 15 de abril de 1889', Revista de Higiene, 11 (1889), 270.

${ }^{81}$ Junta Central de Higiene, 'Sesión extraordinaria del 9 de mayo de 1889', Revista de Higiene, 11 (1889), 283-93.

82 Nicolas Osorio y Proto Gomez, 'Epidemia de fiebre tifoidea', Revista de Higiene, 16 (1889), 475-6.

${ }^{83}$ Ibid., 475-9.

${ }^{84}$ Junta Central de Higiene, 'Informe presentado al Sr. Mnistro de Gobierno por el Secretario de la Junta Central de Higiene, sobre los trabajos de esta Corporacion en los años de 1896 a 1898', Revista de Higiene, 56 and 57 (1899), 612-20.

85 Pablo Garcia Medina, 'Higiene de Bogotá', Revista de Higiene, 56 and 57 (1899), 577.

86 The medical societies created between 1873 and 1893 are: the Sociedad de Medicina y Ciencias Naturales de Bogotá - SMCN - 1873, called the Academia Nacional de Medicina (ANM) from 1891 onwards; the Academia 
they no longer needed to resort to medical geography as a rhetorical tool for building a national medical culture and for emphasising their capability of producing original knowledge claims. It would be in the 1890s when bacteriological considerations of typhoid fever and of other pathologies such as yellow fever and leprosy were finally accepted, that bacteriology would eventually take the place of medical geography in making claims of originality of knowledge, but on different grounds. ${ }^{87}$

\section{Conclusions}

The Colombian medical community used a national dialogue to make sense of typhoid fevers. Drifting away from the 'centre and peripheries' approach to science and medicine, the history of typhoid fever has to be understood within the broader concerns of the medical community in question. Like their North American and European counterparts, Colombian doctors set the boundaries of typhoid fever in relation to the other continuous fevers, exanthemata and typhus, increasingly considering it to be a distinct disease. Like their counterparts, Colombian physicians framed typhoid fever within the neo-Hippocratic model of specific, predisposing and occasional causes. Nevertheless, in contrast to what scholars have shown for Europe and the US, Colombian physicians used medical geography in their approach to typhoid fever. What makes this case interesting is the fact that in the 1860s and 1870s, debates about typhoid fever were driven by the concerns of Colombian doctors regarding the project of building a national medical culture which was supposed to be founded on the study of local pathologies or medical geography. The project sought to consolidate the medical profession and thus, by emphasising the local origin or particularities of diseases according to medico-geographical ideas, Colombian doctors could thus claim more authoritative knowledge on these matters than their European peers. They therefore highlighted both the particularities of typhoid fever in Colombia and the climatic determinism of periodic fevers (Magdalena fevers) in contrast to fevers in Europe while they openly contested European accounts such as Boudin's laws. Furthermore, the emphasis on symptoms as a diagnostic tool, the uneven use of thermometry for differential diagnosis, and most importantly, the fear that periodic paludic fevers could appear along with typhoid fever in the highlands, specifically in Bogotá, greatly shaped debates regarding the very nature of typhoid fever during the following decades in Colombia.

Contrary to what historians have said with respect to other regions, in Colombia the theory of the germ cause of typhoid fever was strongly criticised by 1883 . Even if one physician used it to deal with the possible problem of paludic fevers occurring together with typhoid fever in Bogotá, the dominant position was that of rejection. By 1890, the theory of spontaneous origin of typhoid fever had been used to argue against the germ cause theory, an argument that does not seem to have been raised in relation to any other disease in the Colombian context. Nevertheless, despite these criticisms of Pasteurian theories and claims that medicine should not surrender to bacteriology, hygienic and clinical practices to prevent typhoid fever had become Pasteurian before these concerns were raised, as revealed during the epidemics of the last two decades of the nineteenth century.

de Medicina de Medellin, 1887; the Sociedad de Medicina del Cauca, 1888; and the Sociedad de Ciencias Médicas - Bucaramanga, 1893.

87 See Pohl-Valero and Garcia, op. cit. (note 12). 
By the end of the century, concerns regarding typhoid fever had dramatically changed in comparison to those of the medico-geographical era - and not necessarily because of bacteriology. By the 1890s doctors had managed to consolidate the institutional basis for their profession and therefore no longer needed to resort to the rhetoric of constructing a national medical culture based on medical geography. Bacteriological theories, mixed with miasmatic notions, would take the place that medical-geography once held.

By considering the intellectual and professional concerns that guided Colombian medical opinion regarding typhoid fever, this paper illustrates how a particular medical community argued to have produced original knowledge claims, a reality which does not fit in with the still pervasive 'centre and peripheries' approach to the history of science and medicine. 